1975

\title{
Giovanni Mercurio da Correggio's Appearance in Italy as Seen through the Eyes of an Italian Jew
}

David B. Ruderman

University of Pennsylvania, RUDERMAN@SAS.UPENN.EDU

Follow this and additional works at: http://repository.upenn.edu/history_papers

Part of the Christian Denominations and Sects Commons, Cultural History Commons, European History Commons, History of Religion Commons, $\underline{\text { Intellectual History Commons, and }}$ the Jewish Studies Commons

\section{Recommended Citation}

Ruderman, D. B. (1975). Giovanni Mercurio da Correggio's Appearance in Italy as Seen through the Eyes of an Italian Jew. Renaissance Quarterly, 28 (3), 309-322. http://dx.doi.org/10.2307/2859808

At the time of this publication, Dr. Ruderman was affiliated with the University of Maryland, College Park, but he is now a faculty member at the University of Pennsylvania.

This paper is posted at ScholarlyCommons. http://repository.upenn.edu/history_papers/40

For more information, please contact repository@pobox.upenn.edu. 


\title{
Giovanni Mercurio da Correggio's Appearance in Italy as Seen through the Eyes of an Italian Jew
}

\begin{abstract}
The literary evidence describing the revelation of the strange Christian prophet Giovanni Mercurio da Correggio in the communities of Italy and France at the end of the fifteenth and the beginning of the sixteenth century has been treated with considerable interest by a number of scholars. W.B. McDaniel was the first to publish the existing evidence on this unusual figure, together with the text of a hermetic plague tract attributed to him with an English translation. These sources portray a divinely inspired prophet, together with his wife, five children, and his disciples, making his way as a mendicant through Italy and France. Mercurio sees as his task the reprobation of all the sins of the Catholic Church and Christian peoples. He is empowered with the magical gift of the Supreme Being to prepare an antidote against the horrendous plague. ${ }^{1}$ He not only gains the loyalty of the uneducated masses who marvel at his wondrous abilities but is surrounded by a select retinue of outstanding scholars who are equally impressed by his prophecy. The latter include Carlo Sosenna, a lecturer at the University of Ferrara and author of a scholastic commentary to one of Mercurio's sonnets; Ludovico Lazzarelly, an avid hermetic who describes Mercurio's appearance in Rome in 1484; and Trithemius, another hermetic and mystic who relates Mercurio's appearance at Lyons at the end of the fifteenth century. ${ }^{2}$

\section{Disciplines}

Christian Denominations and Sects | Cultural History | European History | History | History of Religion | Intellectual History |Jewish Studies
\end{abstract}

\section{Comments}

At the time of this publication, Dr. Ruderman was affiliated with the University of Maryland, College Park, but he is now a faculty member at the University of Pennsylvania. 


\section{RENAISSANCE QUARTERLY}

Edited by ELIZABETH STORY DONNO

Associate Editors S. F. JOHNSON C. WILLIAM MILLER MARGARET L. RANALD CHARLES SEYMOUR, JR. M. A. SHAABER ROBERT E. TAYLOR

\section{Giovanni Mercurio da Correggio's Appearance in Italy as Seen through the Eyes of an Italian Jew*}

\section{by DAVID B. RUDERMAN}

THE literary evidence describing the revelation of the strange 1 Christian prophet Giovanni Mercurio da Correggio in the communities of Italy and France at the end of the fifteenth and the beginning of the sixteenth century has been treated with considerable interest by a number of scholars. W. B. McDaniel was the first to publish the existing evidence on this unusual figure, together with the text of a hermetic plague tract attributed to him with an English translation. These sources portray a divinely inspired prophet, together with his wife, five children, and his disciples, making his way as a mendicant through Italy and France. Mercurio sees as his task the reprobation of all the sins of the Catholic Church and Christian peoples. He is empowered with the magical gift of the Supreme Being to prepare an antidote against the horrendous plague. ${ }^{1}$ He not only gains the loyalty of the uneducated masses who marvel at his wondrous abilities but is surrounded by a select retinue of outstanding scholars who are equally impressed by his talents and are unquestionably convinced of the authenticity of his prophecy. The latter include Carlo Sosenna, a lecturer at the University of Ferrara and author of a scholastic commentary to one of Mercurio's

* This essay is based substantially on a part of my doctoral dissertation submitted to the Hebrew University of Jerusalem in June 1974, under the supervision of Professor Haim Beinart, 'Abraham Farissol: An Historical Study of his Life and Thought in the Context of Jewish Communal Life in Renaissance Italy' (in Hebrew). I would also like to thank Professor Eugene P. Rice, Jr., of Columbia University, who first called my attention to the literature on Mercurio.

1 'An Hermetic Plague-Tract by Johannes Mercurius Corrigiensis,' first published in Fugitive Leaves of the College of Physicians of Philadelphia, 1935-36 (mimeographed); later revised and republished in Transactions and Studies of the College of Physicians of Philadelphia, Series IV, 9 (1941-42), 96-111, 217-225; See especially McDaniel's summary of the Oratio ad sanctam crucem, pp. 217-218. 
sonnets; Ludovico Lazzarelli, an avid hermetic who describes Mercurio's appearance in Rome in 1484; and Trithemius, another hermetic and mystic who relates Mercurio's appearance at Lyons at the end of the fifteenth century. ${ }^{2}$

Kurt Ohly also published a detailed account of the Epistola Enoch, Lazzarelli's description of the prophet's visit to Rome. On the basis of a comparison of this text with three prefaces dedicated by Ludovico 'Enoch' Lazzarelli to Mercurio, along with other texts attributed to the prophet, Ohly maintained that Lazzarelli was not only the author of the Enoch letter but also the plague tract and the rest of the prophet's writings. He concluded that Mercurio was no more than a literary fiction invented in the mind of Lazzarelli or, at best, an insignificant preacher who had been elevated to the stature of a divine prophet through Lazzarelli's writings. Ohly defended the plausibility of this conclusion in light of the paucity of contemporary references to Mercurio's appearance and the probability that those remaining reports of his existence, including the detailed account of Trithemius, were simply based on the initial account of Lazzarelli. ${ }^{3}$

Paul Oskar Kristeller subsequently published a study on Lazzarelli as well as new evidence regarding Mercurio, specifically a sonnet written by the prophet with Sosenna's commentary. As an appendix to his second article, he published additional sources on the actual existence of Mercurio. The references included evidence of the fact that Mercurio visited Florence, Cesena, Lucca, as well as Rome. On the basis of these

2 On Sosenna, see McDaniel, p. 219; Paul Oskar Kristeller, 'Ancora per Giovanni Mercurio da Corregio,' in Studies in Renaissance Thought and Letters (Rome, 1956), pp. 251ff.; G. Pardi, Lo studio di Ferrara nei secoli XV e XVI (Ferrara, 1903), p. 148. On Lazzarelli, see McDaniel, pp. 220, 222ff.; Kurt Ohly, 'Johannes “Mercurius” Corrigiensis,' Beitraege zur Inkunabelkunde, n.f., II (1938), 140ff.; L. Thorndike, A History of Magic and Experimental Science, v (New York, 1941), 533; P. O. Kristeller, 'Marsilio Ficino e Ludovico Lazzarelli, Contributo alla diffusione delle idee ermetiche nel Rinascimento,' in Studies in Renaissance Thought and Letters (Rome, 1956), pp. 222-240, and 'Lodovico Lazzarelli e Giovanni da Corregio, due Ermetici del Quattrocento, e il manoscritto II.D.I.4 dell Biblioteca Comunale degli Ardenti di Viterbo,' in Biblioteca degli Ardenti della Città di Viterbo, Studi e Ricerche nel $150^{\circ}$ della Fondazione, ed. A. Pepponi (Viterbo, 1960), 13-37. I have used an offprint of the article in the Columbia University Library, paginated 1-25, from which I cite. See also the references cited in this last article on p. 8 , n. 18. On Trithemius, see McDaniel, pp. 220, 222ff.; Ohly, pp. 140ff.; Thorndike, v (1934), 524; vi (1941), 439.

3 Ohly, pp. 140ff., and McDaniel, pp. 221ff., who also discusses Ohly's contention. The entire Epistola Enoch was later published along with other selections of Lazzarelli's writings in Testi umanistici su l'ermetismo, ed. E. Garin, M. Brini, et al., Archivio di filosofia (Rome, 1955), pp. 34-47. 
new sources, Kristeller argued that there was no longer any doubt concerning the historical reality of Mercurio da Correggio. In a later article, he provided still further references to Mercurio, including additional works by the prophet himself. ${ }^{4}$ Adding to this evidence, Eugenio Garin later published another document describing Mercurio's appearance in Florence in 1486, containing further biographical material on the prophet. ${ }^{5}$

To the growing number of references to Mercurio da Correggio another source can now be added which completely establishes him as an authentic historical personality in his own right, while revealing supplementary evidence on his broad appeal and the motivation of Catholic authoritics to silence and punish him. Unlike the other contemporary reports previously discovered by scholars, there can be no question regarding the personal involvement of this witness who recorded the spectacle of Mercurio in three Italian cities as a totally unimpassioned observer. This source is found in a polemic against Christianity entitled Magen Avraham, written by Abraham Farissol (14521528?), the Italian Jewish scribe, cantor, educator, and author. Farissol traveled widely throughout Italy during the second half of the fifteenth and the early sixteenth centuries, while establishing his permanent residence in the city of Ferrara. ${ }^{6} \mathrm{He}$ wrote his polemic in Hebrew, ostensibly the result of a debate or series of debates at the ducal court of Ferrara between Farissol and two learned Christian theologians between 1487 and 1490 . Upon the conclusion of these debates, Farissol probably revised and appended new material to his original manuscript as late as the second decade of the sixteenth century. ${ }^{7}$ While most of the com-

4 Kristeller, 'Marsilio Ficino e Ludovico Lazzarelli . . .,' pp. 222-240; 'Ancora per Giovanni Mercurio da Correggio,' pp. 249-257, esp. p. 257; and 'Lodovico Lazzarelli e Giovanni da Corregio ...,', pp. 10-13, 20-22.

5 Eugenio Garin, Giovanni Pico della Mirandola, Comitato per Celebrazione Centenarie (Mirandola, 1963), pp. 39-40.

6 On Farissol, see my doctoral dissertation and my Hebrew lecture, to be published in the proceedings of the Sixth World Congress of Jewish Studies, held in Jerusalem, August 1973, entitled 'Abraham Farissol's Iggeret Orhot Olam in its Historic Context.'

7 Samuel Lowinger previously published selections from Magen Avraham along with a discussion of the time of Farissol's disputation and of the manuscripts of Farissol's polemic. Cf. Samuel Lowinger, 'Selections from Magen Avraham of Abraham Farissol' (Hebrew), Ha-Zofeh, 12 (1927-28), 277-297; and 'Récherches sur l'ocuvre apologetique d'Abraham Farissol,' Révue des études juives, 105 (1939), 23-52, as well as my corrections and additions to his discussion in my thesis, chapter $\mathrm{v}$, and appendix II. A list of approximately thirty-five extant manuscripts of this composition is also found in appendix II of my thesis. 
position purports to provide an actual summary of the 'debate' proceedings, in reality the author chose to include much extraneous material clearly unrelated to the disputation itself.

A case in point is the chapter entitled 'Concerning some strange doctrines deviating from those of the generality of believers whose way I have observed and with whom I have conversed.' ${ }^{2}$ In this chapter, Farissol presents four unusual views with which he came in contact during his sojourn in Ferrara and during his various excursions to other Italian communities. While the first two views depict groups or individuals with a clear relationship to Judaism, the remaining two describe phenomena essentially related to the Christian world. H. H. Ben Sasson, the first scholar to discuss and publish sections of this chapter, placed these final two descriptions in the correct context of pre-Reformation and reformist tendencies of Renaissance Italy but failed to identify the specific historical allusions described by these passages. Only one of these passages will concern us here, referred to by Farissol as the third view. This passage reads in part:

I myself saw in my time and in my town a man who was a great celebrity at the time, who used to go and preach and exhort in most of the gentile regions, and would exalt himself . . . by his wisdom . . until he almost imagined his utterances to be inspired by the Holy Spirit, prophesying and interpreting the Torah. He called himself Son of God, Mercurius Trismegistus, Enoch and Methuselah. . . . Their scholars, however, answered him sharply, as for instance in Rome, where he was cast into prison in my presence, as also in Bologna. But through the power of his rhetorical quips, for he was certainly eloquent, he escaped and fled with his friends, the devotees of his philosophy and doctrine. Thus he went forth from prison, he and his retinue with him, wandering and exhorting in various lands, dressed in sackcloth and girded with ropes, to this very day, during my own lifetime....9

Upon examining Farissol's description of the anonymous man he presents, the similarity of his description with all the other sources of

8 Selections from this chapter (numbered chapter 5 in most manuscript versions), along with a discussion of the views found there, were first published by Hayim Hillel Ben-Sasson, 'The Reformation in Contemporary Jewish Eyes,' preprint from Proceedings of the Israel Academy of Sciences and Humanities, 4 (Jerusalem, 1970), 249-254 (also published in an original Hebrew version).

${ }^{9}$ Magen Avraham, chapter 5. I have consulted a number of manuscripts in quoting Farissol's description here, especially mss. New York-Jewish Theological Seminary of America-Adler 254, Oxford Bodleian 2295.2, and the manuscript utilized by BenSasson, MS. Jewish National and University Library, Jerusalem, Heb. $8^{\circ} 783$, edited by Z. A. Poznanski from several manuscripts. I have also consulted the English translation of this passage in Ben-Sasson's article in making my own translation of this passage. 
Mercurio mentioned above is most striking. Farissol calls this man a great celebrity who wandered through most of the gentile regions, preaching, interpreting the Holy Scriptures, and extolling his wisdom almost to the extent that he imagined his utterances to be inspired by the Holy Spirit. The itinerant nature of Mercurio's prophetic mission is clearly illustrated by all the sources mentioned above. His self-exaltation concerning his incredible knowledge is also attested to by the sources. Trithemius writes, for example:

... For he boasted that he comprehended all the learning of all the ancient Hebrews, Greeks and Latins and despised practically all the ancients, philosophers as well as theologians, since compared to him only, he said, they were all unlearned and not one of them appeared to be wholly wise regarding the mysteries. Whence he confessed that he was versed in all the knowledge of the world, understood all the mysteries and arcana of natural things, was able to discover the deepest meanings of the scriptures, and knew everything that mortal man could know. ${ }^{10}$

In the same passage, his divine inspiration is also mentioned by Trithemius: 'He averred that he had been born for the highest things, asserted that he was full of divine power, and declared great things were possible.' Elsewhere he is identified with the spirit and wisdom of Jesus personified. ${ }^{11}$ Similarly in the Enoch chronicle, Mercurio distributes scrolls which state 'Ego Joannes Mercurius de Corigio, sapientiae angelus Pimanderque in summo ac maximo spiritus Jesu Christi excessu, hanc aquam regni pro paucis, sic super omnes magna voce evangelizo.' ${ }^{2}$

Farissol mentions the names by which the prophet called himself: the son of God, Mercurius Trismegistus, Enoch, and Methuselah. These names are similar to the names of Mercurio found in the Latin sources. In the first preface of the sonnet discovered by Kristeller, Mercurio is called Mercurius Trismegistus. ${ }^{13}$ While he is not specifically referred to as the son of God, similar appellations are used to describe him as one enveloped in the divine spirit and speaking 'in the name of the living and dreadful God.' ${ }^{14}$ Farissol probably calls him Enoch from his asso-

10 Translated by McDaniel, p. 220.

${ }^{11}$ Exhortationes in Barbaros Thurcos Scythas . . perorate, Lyons, May 26, 1501, in McDaniel, p. 217.

12 Ohly, p. 136; Garin and Brini, p. 41.

13 McDaniel, p. 220; Kristeller, 'Ancora per Giovanni Mercurio da Correggio,' p. 250.

${ }_{14} \mathrm{McDaniel}$, p. 219; Ohly, p. 136. The direct appellation of son of God in describing Mercurio had to be avoided, understandably, but the implication that he was in fact the son of God is nevertheless made by some of his enthusiastic followers. See the discussion on Lazzarelli below. 
ciation with the Enoch chronicle ascribed to Lazzarelli, which Farissol quite possibly had read. Only the name Methuselah is absent from the sources. The latter may have been another name of Mercurio connoting his unusual wisdom and longevity, acquired by knowing the secrets of life.

Farissol also mentions his rhetorical skills and his natural eloquence, which is also confirmed by other sources. The Enoch chronicle remarks that even though he was not learned in grammar and rhetoric, he possessed a natural eloquence. ${ }^{15}$ Farissol adds that he traveled together with his household, wandering and exhorting in various lands, dressed in sackcloth and girded with ropes. The same description is found in most of the other sources where he is described as traveling with his wife and five children as well as his other followers. Similarly, the description of the sackcloth and ropes is the same as in the other sources. ${ }^{16}$ Farissol's description is so close to the portrait already gleaned from these sources that one must conclude accordingly that he too is speaking of Mercurio da Correggio.

The precise time at which Farissol witnessed Mercurio is more difficult to determine but here, too, he adds a number of facts which help to establish the specific circumstances of his meeting. Farissol mentions explicitly that he saw him with his own eyes in Ferrara. The fact that Mercurio visited Ferrara and had contact with its citizens is all the more likely in view of the sonnet published in Mercurio's name with the scholastic commentary of Carlo Sosenna, the above-mentioned professor of the University of Ferrara, who was on personal terms with Duke Ercole I. ${ }^{17}$ One may surmise that when Mercurio came to Ferrara, he was received sympathetically by the court of Ercole and the duke himself, given the latter's unusual interest in astrology, divination, and the miraculous, and his later relationship to Savonarola, a similar prophetic figure. ${ }^{18}$

15 McDaniel, p. 219; Ohly, p. 135; Garin and Brini, p. 37. Calmeta similarly writes of his natural eloquence: 'essendo di facondia e di ardente pronuncia dalla natura dotato ...' (quoted in Kristeller, 'Lodovico Lazzarelli e Giovanni da Corregio . . . ,' p. 11).

16 Oratio ad sanctam crucem, in McDaniel, p. 217; as well as Exhortations, p. 218; Enoch Chronicle, p. 219 (which claims he left his family in Bologna); Cesena Chronicle, p. 220; Trithemius, p. 220. See also Ohly, p. 137.

17 Kristeller, 'Ancora per Giovanni Mercurio da Correggio,' pp. $251 \mathrm{ff}$.

18 On Ercole's relationship to Savonarola, see Edmond Gardner, Dukes and Poets in Ferrara (New York, 1904), pp. 324ff., $363 \mathrm{ff}$.; Luciano Chiappini, 'Girolamo Savonarola ed Ercole I d'Este,' Atti e memorie della deputazione provinciale ferrarese di storia patria, n.s., 7, parte 3 (Ferrara, 1952-53), 45-53; and more generally, Werner I. Gundersheimer, 
Besides Ferrara, Farissol also claimed that he saw this prophet in Rome where he was rebuked by Christian scholars and cast into prison. This was the fate of Mercurio in Bologna also, from which, through the power of his rhetorical skills, and with the help of his followers, he managed to escape. The other sources indicate that he visited Rome on a number of occasions. His most auspicious visit was described in the Enoch chronicle where he appeared before Pope Sixtus IV, the bishops, nobles, and a huge mass of people on Palm Sunday, April 11, 1484 . There is no mention of hostility on the part of his Roman audience to his exhortations, nor is there any mention of the fact that he was thrown into prison. In the Oratio ad sanctam crucem, published in 1499, he is again found in Rome, where he delivered another sermon. This time there is no mention of the aftermath of his appearance. ${ }^{19}$ Mercurio's sonnet with Sosenna's commentary also was written on the occasion of Mercurio's visit to Rome. In this case, the poet addressed himself to Alexander VI, the successor of Sixtus IV whom he had previously addressed in 1484. Kristeller dates this appearance sometime after 1492, during Alexander's reign. ${ }^{20}$ This could be the same visit described in the Oratio, published in 1499, which may have described an event several years earlier. Thus Mercurio visited Rome either two or three times, first in 1484, then some time after 1492, and perhaps around 1499, if the Oratio describes a sermon contemporary with the date of publication

Ferrara: The Style of a Renaissance Despotism (Princeton, N.J., 1973), pp. 186ff. On the influence of astrology and magic at Ercole's court, see Giulio Bertoni, La biblioteca estense e la cultura ferrarese ai tempi del duca Ercole I (1471-1505) (Torino, 1903), pp. 117ff., 126ff; Antonio Rotondò, 'Pellegrino Prisciani,' Rinascimento, 11 (1960), 69-110. Professor Kristeller (in 'Lodovico Lazzarelli e Giovanni da Corregio . ...' p. 11, n. 30) has already suggested Mercurio's possible link to the same Northern Italian feudal family of da Correggio which produced Niccolò da Correggio (1450-1508), the poet, playwright, and diplomat who was in close contact with the ducal court of Ferrara. Pompeo Litta, in his family tree of the da Correggio family (Famiglie Celebri Italiane, II [Milan, 1825]), does in fact list two lesser known members of the family with the name Giovanni, both of them living at the end of the fifteenth century. Besides Niccolò, a number of other members of this distinguished family were also in close contact with the Este court including Manfredo and Antonio da Correggio (see Litta above). If Giovanni Mercurio was indeed a relative of this distinguished clan, his connection with Ercole is all the more understandable. On Niccolò da Correggio and his connections with the Este house, see Gundersheimer, pp. 211, 223, 258, 260; Bertoni, p. 147; and Alda Arata, Niccolò da Correggio nella vita letteraria e politica del tempo suo (1450-1508) (Bologna, 1934).

19 On his first visit, see Ohly, pp. $135 \mathrm{ff}$; McDaniel, p. 219; Garin and Brini, pp. 37ff.; On his visit described in the Oratio, see McDaniel, p. 217.

${ }^{20}$ Kristeller, 'Ancora per Giovanni Mercurio da Correggio,' p. 250. 
rather than a past event. In all three (or two) cases, there is no mention of hostility or imprisonment. Regarding his sojourn in Bologna, the Enoch chronicle mentions only that after departing from Rome in April 1484, he returned to his family in Bologna. No reference to any hostility in that city is recorded. Only the document published by Garin confirms at least part of Farissol's statement that Mercurio, before coming to Florence where he was severely punished by the authorities on July 4, 1486, had been imprisoned some time earlier in Bologna but had subsequently been released. ${ }^{21}$ This sequence of events-his sermon in Rome, his journey and imprisonment in Bologna, and his eventual release from that city described by Farissol-most closely corresponds to Mercurio's itinerary for April 1484, and immediately thereafter. Thus Farissol most likely observed Mercurio's performance in Rome and was aware of his subsequent journey to Bologna and later departure from that city. What he fails to mention is his arrival in Florence over two years later. One may thus conclude that he wrote his account of Mercurio between April 1484 and July 1486-perhaps immediately after the prophet's appearance in Rome and Bologna.

This suggestion for dating Farissol's remarks is further strengthened by the known facts of the author's whereabouts during this same period. During the first half of the 1480's, Farissol had left Ferrara and was traveling to other Italian communities, acquiring work as a Hebrew scribe for various Jewish banking families. In May 1480, he was in Mantua; and during 1481-82, he was living at the home of the Jewish banker Samuel da Pola, in Sermide, near Mantua. ${ }^{22}$ There exists no record of his wanderings until August 7, 1484, when he concluded a manuscript in Bologna at the home of Joseph Caravata. By May of the same year, he returned to Mantua where he was engaged again in copying a Hebrew manuscript. ${ }^{23}$ Therefore, it is conceivable that Farissol had been in Rome in April 1484, where he first heard of

21 Garin, p. 40.

22 Farissol was in Mantua in 1480 when he copied Ms. Heb. $8^{\circ} 5492$ in the National and University Library, Jerusalem, for an unknown female patron. During 1481-82, Farissol copied the following Hebrew manuscripts for Samuel da Pola in Sermide; Mss. London-British Museum 95; Cambridge add. 1821/1; London-British Museum 622; Parma DeRossi 79.

${ }^{23}$ In Bologna, he copied ms. Cincinnati hUC 331; ms. Firenze-Laurenziana Or. 475 may have been completed by Farissol in Mantua in 1485. In addition, Farissol definitely completed another manuscript in Mantua in that same year. $C f$. S. Kirschstein, Die Judaica-sammlung (München, 1932), p. 14, n. 215. 
Mercurio. ${ }^{24}$ His own work for Caravata took him to Bologna at precisely the same time as Mcrcurio's arrival, subsequent imprisonment, and release. Farissol again saw Mercurio in Ferrara, but this date is impossible to determine preciscly.

One of the most interesting facets of Farissol's testimony is his reference to the hostility of Mercurio's audience in Rome and Bologna, not previously reported by the Enoch chronicle and confirmed only in part by Garin's document. Thus the latter document and Farissol's testimony provide conclusive evidence that, while Mercurio aroused much excitement and enthusiasm on the part of his followers-among them a large circle of intellectuals - at the same time, he aroused the animosity of the Church to the point where he was accused of heresy. ${ }^{25}$ Concerning the nature of this heresy and the motivation of the Church to punish Mercurio, Farissol also provides some useful hints.

What impressed Farissol about Mercurio was the latter's peculiar understanding of prophecy with which Farissol was not only familiar from seeing him but also from reading his writings. ${ }^{26}$ Farissol describes his prophetic tcaching as follows:

And this was his intention to convey that he too was a son of God emanating from the Godhead with the divine spirit sparkling in him. For he believed that whoever elevated himself and endeavored to gain perfection would attain, in his opinion, the status of a son of God. And this power to achieve spirituality lay, according to his doctrine, within every man, inasmuch as he was no doubt a son of God by his design and understanding and by his inclination to this matter. This is what I understood from him and this represents one of the three views of prophecy advanced by Maimonides in the Guide [Guide to the Perplexed, II, 32], a view in total disagreement with that of the sages of the perfect Torah. [According to this correct view] anyone striving to follow the ways of prophecy, in the manner pursued by the ancient prophets, can never reach the level of true prophecy without divine will and assistance, as it is explained in its appropriate place [Jeremiah 45:3-5] concerning Barukh son of Neriah who sought greatness. Insofar as I understood his words, he thus believed in their Messiah, to wit, that he had reached this degree of perfection through the abundance o

${ }^{24}$ Farissol also mentions in chapter 29 of Magen Avraham that he had visited Rome, where he personally inspected a copy of Jerome's translation of the Psalms.

25 Along with the other intellectuals like Lazzarelli, Trithemius, and Sosenna already mentioned, Garin (pp. 39-40) states that before Mercurio's imprisonment by the inquisitor of Florence, he was also invited to meet with both Pico della Mirandola and Flavius Mithridates, Pico's teacher, in the spring of 1486. I intend to discuss Farissol's relationship with Pico and Mithridates in a future study.

26 'However this man believed and argued the correctness of this false and foolish view that he be called the son of God in his account and in his writings and according to what I understood from his words, so it was ...' (my emphasis). 
his discernment, and through his decision and endeavor to comprehend the intellectual concepts. He attained the status that he held . . through fine understanding of his being and his choice, even though he was the son of God by the breath of His lips, a prophet created and formed without human agency....

While most of the other sources describing Mercurio generally speak about his exceptional abilities, his self-image as a prophet, and his moral exhortations to his audience, they fail to explicate his particular view of prophecy, and especially its applicability to Jesus. Farissol emphasizes that this view is that of the philosophers; yet, given the miraculous character of Mercurio's personality and mission, his description is misleading. A hint at what Farissol was actually describing is already found in Trithemius' portrait of Mercurio. As quoted in part above, Trithemius had described Mercurio as a man versed in all the knowledge of the world, understanding all the mysteries of natural things and full of divine power. He was an expert in alchemy (fully attested by the plague tract) and was capable of making 'propitious what was unpropitious and changing the propitious into the opposite,' accomplished 'by the art of natural magic.' Trithemius goes on to describe the examination by doctors of the court of Louis XII who concluded that Mercurio had more than human wisdom, "but they were utterly ignorant as to whence he had acquired these great powers or where the secret lay hidden in him.'27

The key to understanding Farissol's remarks about Mercurio's prophecy is precisely Trithemius' statement that Mercurio had perfected magical powers. While Mercurio's own art is not spelled out openly in the sources, the magical teaching of some of his most avid admirers associated with the intellectual circles of Florence and other Italian cities have been amply illuminated by a number of scholars. Paul Oskar Kristeller, Francis Yates, D. P. Walker, Eugenio Garin, Wayne Schumaker, and others have fully described the flowering of this hermetic movement in Renaissance Italy.

Fully entrenched in this tradition, which had been revived by Ficino, was Ludovico Lazzarelli-Mercurio's most illustrious admirer and the author of the Epistola Enoch described above. In his Crater Hermetis, written sometime before 1494, Lazzarelli describes a dialogue between the author and King Ferdinand of Aragon, illustrating the hermetic view that man was created to know divine things and to dominate all

27 McDaniel, p. 220. 
creation. Man, through his own capabilities, had the power to become a terrestrial God: 'Apply here all the strength of your soul, beseech, admire, praise, contemplate the divinity. For thus you will be properly disposed for the great secret God-making mystery which, if God help me, I am going to reveal. . . '28 Kristeller summarizes the system of Lazzarelli as follows: True men are capable of creating divine souls which serve God and accomplish supernatural acts. Their spirits are not demons but are those of men who elevate themselves to a divine existence and receive the faculty of prophecy and of performing miracles. This divine generation is dependent upon the relationship of master and disciple (the ability of the former to communicate his special knowledge to the latter). This is precisely the relationship formed between Lazzarelli, the disciple, and his spiritual master, Mercurio. According to Lazzarelli, the source of this theory is the Sefer Yezirah. This work, an allegory, describes how a new man can be formed from the mind of a wise man and can be vivified 'by the mystic disposition of letters through his limbs; for divine generation is accomplished by the mystic utterance of words which are made up of letters as elements. 29 Thus by pronouncing special words, Lazzarelli claimed that he was spiritually transformed by his master. Both student and teacher were remolded by this regeneration into a kind of spiritual brotherhood, symbolized by their taking of the names Mercurio and Enoch.

Kristeller suggested that this process of 'regeneratio' was meant to allude to Christ's inspiration to his disciples by his spirit, now interpreted as the hermetic experience which can be repeated in modern times by the inspired hermetist. Walker has tentatively suggested the

${ }^{28}$ Quoted by D. P. Walker, Spiritual and Demonic Magic from Ficino to Campanella (London, 1958), p. 65.

29 Walker, p. 68. Walker's summary is based on Kristeller, 'Marsilio Ficino e Ludovico Lazzarelli,' pp. 232-240. Neither Kristeller nor Walker were able to locate Lazzarelli's source in Sefer Yezirah. F. Secret (Les Kabbalists Chrétiens de la Renaissance [Paris, 1964], p. 75) also omits this reference. According to Gershom Scholem, introductory chapters appended to the earliest texts of Sefer Yezirah actually describe similar magical practices to that mentioned by Lazzarelli. Lazzarelli may have consulted such an appended version of this composition. On the magical use of Sefer Yezirah in Jewish mystical tradition, see G. Scholem, Kabbalah (Jerusalem, 1962), p. 26, and more fully in the same author's printed lectures, The Beginning of the Kabbalah and Sefer ha-Bahir [Hebrew] (Jerusalem, 1962), pp. 57-63. The popularity of Scfer Yezirah among Christian cabalistic circles is attested by its publication in a Latin translation by G. Postel in 1552 , ten years before the first Hebrew printed edition of the work. It is most ironic that Farissol, a Jew, had learned of this magical practice from a Christian who had in turn mastered the practice through the study of an ancient Jewish text. 
following extension of Kristeller's interpretation of the mystery described by Lazzarelli. It was a magical opcration by which the master provided his disciple with a good demon. The operation consisted mainly of words sung in some special manncr, and the sounds themselves became the demon. The extraordinary part of this mystery is that these created demons were considered as separated bits of the Holy Spirit or the spirit of Christ himself. This operation thus paralleled the same kind of process in God's creation. ${ }^{30}$

Upon examining the hermetic teachings surrounding the strange appearance of Mercurio as articulated by his major disciple, the hostility of the Church to Mercurio's mission becomes quite understandable. The fundamental reason for the Church's condemnation of these magical beliefs was simply that the Church had its own system of magic to preserve. Given the sanctified nature of its belief in miracles, it was unthinkable that there was any room for another system. One of the major efforts of Christian theologians of the sixteenth century was to make a sharp distinction between Christian rites like the Eucharist and any kind of secular magic. ${ }^{31}$ The inherent danger to religion posed by the magical teachings of this hermetic circle was that they claimed to produce the same effects without any divine agent. Faith in a figure like Mercurio threatened to present itself as a rival religion, challenging the basic contention of the Catholic Church that Christian revelation is unique and exclusive and that there is no other legitimate revelation. Moreover, prophecy was now taken out of the domain and control of the Church and placed in the hands of any individual who was capable and willing to prepare himself to master a natural art. What must have been most appalling to the Church authorities was the fact that the uniquencss of the prophecy of Jesus was now brought into question. Like anyone else, Lazzarelli and his colleagucs contended, Christ's gifts came not from a divine source but only from the innate abilities which he developed through his own human endowments. Any man, with

30 Walker, p. 70. This bizarre teaching was not restricted to Lazzarelli alone but was shared by other Italian intellectuals as well, including Giovanni Nesi and Pico della Mirandola. See Donald Weinstein, Savonarola and Florence, Prophecy and Patriotism in the Renaissance (Princeton, 1970), pp. 192ff., and Francis A. Yates, 'Giovanni Pico della Mirandola and Magic,' in L'Opera e il pensiero di Giovanni Pico della Mirandola nella storia dell'umanesimo, Convegno internazionale, I, Relazioni (Firenze, 1965), pp. 159-203, esp. pp. 182-188, republished as the fifth chapter of her book, Giordano Bruno and the Hermetic Tradition (Chicago, 1964).

31 Walker, p. 36. 
the aid of a spiritual master, could thus reach the level of Christ if he was capable and prepared to master the science of the occult. No greater heresy could shake the foundations of the Church's teachings.

What is most astonishing in Farissol's description of Mercurio and his teachings is that he, as a Jew, was quite familiar with an intellectual and spiritual climate so alien to his own religious tradition. Yet he not only observed Mercurio on a number of occasions, but he openly admitted that he was familiar with his writings. What he probably meant was that he was conversant in the writings of Mercurio's followers, especially Lazzarelli. The fact that he was familiar at lcast with his Epistola Enoch is suggested by his confusion in assuming that Enoch and Mercurio were the same person rather than correctly identifying Enoch (Lazzarelli) as the disciple of his spiritual master, Mercurio. His ability to capsulize accurately the essence of Mercurio's teachings, as paralleling the second view of prophecy according to Maimonides, illustrates clearly a wide knowledge of these hermetic views, one conceivably larger than he chose to reveal in his short description of the prophct. Moreover, his immediate recognition of the ultimate threat of Mercurio's prophetic teaching to all religious faiths, including his own, reveals a degree of discernment only available to one who was intimately familiar with an intellectual milieu capable of producing such a doctrine. In short, Farissol's testimony of Mercurio, written in Hebrew and read by an exclusively Jewish audience, provides a striking illustration of the surprising diffusion of hermetic ideas in Renaissance Italy, far beyond the select intellectual world of Christian scholars and even beyond the larger Christian following charmed by Mercurio's magnetic personality.

UNIVERSITY OF MARYLAND

\section{APPENDIX}

\section{An Additional Note on Farissol's Hermetic Knowledge}

In chapter 25 of Magen Avraham, Farissol lists a number of ancient books that he had seen: works of the Sabians and Nabateans, of Appolonius of Tyana-especially his Iggeret ha-Talisman, as well as those of Honein b. Ishak. While his reference to these works is made in regard to another subject entirely, that of the human origin of the Messiah, his recall of such titles is nevertheless illuminating in the context of the Mercurio passage. In his comment, Farissol argues for the necessity of a human agent in any religious upheaval by pointing to the example of 'idolatry' which was also introduced by special human agents. This he learned from his reading of the above- 
mentioned compositions. While Maimonides had already referred to works by the Sabians and Nabateans in his Guide to the Perplexed (III, 29) and may have represented Farissol's source in this passage, the references to the compositions of Honein and Apollonius appear to be works which Farissol had actually read. The Iggeret ha-Talisman of Apollonius and the Arabic translations of Honein have been previously discussed by M. Steinschneider and others. (See especially M. Steinschneider, Die Hebraeischen Uebersetzungen des Mittelalters und die Judens als Dolmetscher, I [Berlin, 1893], 846-848; 'Apollonius von Thyana [oder Balinas] bei den Arabern,' Zeitschrift der Deutschen Morgenländischen Gessellschaft, 45 (1891), 439-446; Thorndike, I [New York, 1925], 257; George Sarton, Introduction to the History of Science [Baltimore, 1927], p. 5870). The common source for Apollonius of Tyana is the legendary biography written in Greek by Philostratus. It was translated into Latin only in the fifteenth century and was first published by Aldus as late as 1501. (See G. R. S. Mead, Apollonius of Tyana, The Philosopher-Reformer of the First Century, A.D. [New Hyde Park, 1966], p. 42.) On the other hand, Steinschneider (in his article on Apollonius) has described a number of medieval Arabic works and Hebrew translations from the Arabic on the subjects of magic, alchemy, and astrology, all alleged to be the work of Apollonius, without any substantial proof for such an allegation. In the course of time, the historical A pollonius and his legendary counterpart became indistinguishable. Farissol's description of Apollonius and his work on talismans clearly refers to the author (authors?) of these medieval Arabic works on magic and related subjects. One composition attributed to Apollonius (On the Influence of Pneumatica described by Steinschneider, 'Apollonius ...,' pp. 442-443) contains an introduction based on the same composition mentioned by Farissol, the Iggeret ha-Talisman. While Honein was generally known as an Arabic translator of scientific and medical texts from the Greek, he also translated some of these same magical texts supposedly written by Apollonius, including the same work in which the Iggeret ha-Talisman is mentioned. (Steinschneider, 'Apollonius . . .' pp. 442443; Die Hebraeischen . . . p. p. 846.) Since Farissol refers to Honein's compositions as works of idolatry (an appellation he would hardly use to refer to medical or philosophical works) and since he mentions them together with Appollonius' work on the talismans, he may have meant Honein's translations of Apollonius. The references to the magical works of Apollonius in medieval Hebrew literature are few but their constant appearance in this same circle of Renaissance hermetics is noteworthy. They represented part of the sacred writings of this profound wisdom literature assiduously collected by these same circles. Ficino quoted Apollonius of Tyana (see Giuseppe Saitta, Marsilio Ficino e la filosofia dell'umanesimo [Firenze, 1943], p. 129). One of Pico della Mirandola's later Jewish teachers, Yohanan Alemano, had occasion to quote Apollonius (A. Neubauer, Catalogue of the Hebrew Manuscripts in the Bodleian Library [Oxford, 1886], p. 539, n. 1535). Agrippa of Nettesheim quoted Apollonius; Trithemius himself interpreted the mystical appearance of Mercurio by referring to similar rites practiced by Apollonius of Tyana (see Yates, Giordano Bruno, p. 141; Garin and Brini, p. 32, n. 13). Farissol's reference to these esoteric works affords another small glimpse of the latter's impressive knowledge of an occult tradition regarded with particular fascination by his Christian contemporaries. 